\title{
Pelatihan Bahasa Inggris Pada Pedagang Kain Tenun Di Desa Pringgasela Melalui Direct Selling
}

\author{
${ }^{1}$ Fathurrahman Imran, ${ }^{2}$ Aprianoto, ${ }^{3}$ Komang Dedy Sandiarsa, ${ }^{4}$ Muhammad Muhlisin, \\ ${ }^{5}$ Muhammad Asrul Hasby ${ }^{6}$ Edi Firman \\ ${ }^{1}$ Prodi Pendidikan Bahasa Inggris, FBMB, UNDIKMA, Jl. Pemuda No. 59A, Mataram, Indonesia \\ 83125 \\ Email Korespondensi: fathurrahmanimran@ikipmataram.ac.id
}

\begin{abstract}
Pringgasela is one of the tourism places in Lombok island which is located at Pringgasela Sub-district, East Lombok Regency. Pringgasela has been announced as a Fabric Industry Centre in Lombok island, the best quality of fabrics is produced by the fabric craftsmen and craftswomen in that place, this fabric industry is important to support the local economic system of Pringgasela's society. Foreign tourists are the target market of the fabric sellers in global scale; however, this opportunity was not supported by the English communication skill of the sellers. This program is aimed to train and facilitate the fabric craftsmen, craftswomen and the fabric sellers of English communication skill by using Direct Selling gradually and continuously, so they could improve their skill in English communication, especially in promoting their products. Technically, the objectives of this program were; 1). to train the the fabric craftsmen, craftswomen and the fabric sellers of English communication skill, so they could promote their products to the foreign tourists effectively and efficiently; 2). as the alternative solution for the fabric sellers, in which they would not rely their target profit to the local guide or travel agency anymore. The method of this program has been done through four steps; 1). Planning; 2). Action; 3). Guiding; and 4). Reflection and Evaluation. During the process of the program, the trainers team monitor the participants by interviewing them related with the material, the method used and the tutors of this program. Generally, the participants gave a positive response, they stated that this program was a good training program and the materials given were appropriate for them that clearly explained by the professional tutors. Based on the calculation data, the responses of the participants were; 1) $83 \%$ (very good category); 2). $8 \%$ (good category); 3). 8\% (enough category); and 4) $0 \%$ (less category).
\end{abstract}

Keywords: Fabrics Seller, Direct Selling

Abstrak. Pringgasela adalah salah satu desa wisata di pulau Lombok yang berada di kecamatan Pringgesela, Kabupaten Lombok Timur. Pringgasela sudah menjadi sentra industri kain tenun di pulau Lombok. Kain tenun berkualitas export banyak diproduksi oleh para pengrajin di desa tersebut, hal ini berperan penting dalam menunjang peningkatan perekonomian masyarakat setempat. Wisatawan asing menjadi sasaran utama bagi para pengrajin dan pedagang dalam memasarkan produk kain tenun mereka dalam skala global, namun sangat disayangkan kondisi ini tidak didukung oleh kemampuan berkomunikasi dalam bahasa Inggris yang baik. PKM ini berupa pelatihan bahasa melalui Direct Selling secara berkala dan berkelanjutan akan menfasilitasi peserta untuk meningkatkan kemampuan berkomunikasi bahasa Inggris pada bidang pemasaran baik secara konsep maupun aplikatif. Program ini bertujuan untuk: 1) Membekali pengrajin dan pedagang kain tenun dengan keterampilan berkomunikasi dalam bahasa Inggris agar mampu memasarkan produk mereka kepada wisatawan asing secara praktis dan efisien, 2) Solusi alternatif agar pengrajin dan pedagang kain tenun tidak lagi bergantung kepada guide dari travel agent untuk memasarkan produk mereka. Metode pelaksanaan kegiatan PKM ini dilakukan dengan menggunakan empat tahapan yakni 1) perencanaan, 2) tindakan, 2) pendampingan, dan 4) refleksi dan evaluasi. Selama proses pelatihan, tim pelaksanaan kegiatan pengabdian melakukan pemantauan kepada peserta pelatihan sekaligus 
melakukan wawancara terhadap materi, metode dan instruktur dalam kegiatan ini. Secara umum para peserta sepakat bahwa pelatihan ini sangat baik dan materi yang diberikan merupakan materi yang sangat dibutuhkan dalam parawisata sedangkan instrukturnya sangat berkompoten. Adapun tanggapan peserta terhadap pelatihan adalah 1) 83\% (sangat baik); 2) 8\% (baik); 3) 8\% (cukup); dan 4) $0 \%$ (kurang).

\section{Kata kunci: Pengrajin/Pedagang Kain tenun, Direct Selling}

\section{PENDAHULUAN}

Nusa Tenggara Barat merupakan salah satu daerah yang mengembangkan tradisi Tenun Ikat Pakan karena berada di daerahdaerah pantai. Desa Pringgasela merupakan salah satu desa yang ada di Kabupaten Lombok Timur yang memiliki kurang lebih sekitar 420 orang penenun khususnya di Dusun Gubuk Daya. Para penenun ini mengembangkan tradisi tenun yang sering disebut Tenun Sesek secara turun-temurun, nama sesek diambil dari asal suara saat menenun "sek sek". Berdasarkan penelitian tentang wastra khususnya tenun yang sudah pernah dikaji para penulis sebelumnya, masih kurang lengkap kajian tentang Tenun Sesek dari desa Pringgasela (Juniati, 2020)

(Hardiyanti, 2017) mengatakan bahwa kegiatan menenun di Desa Pringgasela sudah menjadi profesi sebagian besar warganya. Sehingga bisa dibilang, ada ataupun tidak ada wisatawan yang berkunjung melihat mereka, warganya ya tetap menenun. Hal unik lainnya dari kain tenun yang dihasilkan di Pringgasela yaitu ciri khasnya yang menggunakan pewarna alami, seperti dari akar, dedaunan dan masih banyak lagi. Sedangkan (Solihin, 2016) mengatakan bahwa tenun gedogan merupan pembuatan kain dengan cara ditenun terlebih dahulu. Untuk menjadi sebuah kain membutuh proses yang begitu lama, dari nasin benang, mengeringkan benang, memuyun (menggulung) benang dengan batu yang dilapisi pelastik atau kertas, memindahkan gulungan kembali ke pelting (kayu yang terbuat dari pohon pinang atau kayu-kayu lainnya). Sedangkah menurut

Hasil produksi mereka dijual melalui showroom/ galeri-galeri yang berada di sisi kiri dan kanan jalan sepanjang desa Pringgasela. Selama ini mereka masih menunggu pembeli yang nota bene datang ke sana sebagai wisatawan. Wisatawan datang kesana melalui perantara travel-travel agent. Sebagian dari wisatawan yang datang berasal dari luar pulau Lombok dan juga luar negeri. Pada saat wisatawan terutama wisatawan asing berkunjung, mereka masih mengandalkan tour guide untuk memberikan penjelasan yang tentunya pengetahuan mereka mengenai kain tenun dan proses pembuatannya tidak lebih baik dari penenun itu sendiri.

Kendala bahasa yang dihadapi oleh para pelaku wisata ini, sayangnya masih kurang mendapatkan perhatian dari pemerintah daerah maupun stakeholder terkait. Hal ini didapatkan dari hasil wawancara dengan para pengrajin dan pedagang kain tenun pada tanggal 1 Agustus 2020 bahwa kemampuan berkomunikasi dalam bahasa Inggris mereka peroleh secara otodidak (pengalaman sehari-hari dan masih jauh dari cara pelafalan yang benar). Kondisi tersebut menjadikan pengrajin dan pedagang kain tenun pasif memasarkan produk mereka terutama kepada wisatawan mancanegara. Hal ini tentu sangat disayangkan, sebagaimana perlu disadari bahwa merekalah sasaran utama di sektor pariwisata dalam upaya memasarkan produk secara global. Karenanya, diperlukan adanya program pelatihan dan pembinaan bahasa Inggris bagi masyarakat pelaku wisata: pengrajin dan pedagang kain tenun di desa wisata Pringgasela.

Program pelatihan dan pembinaan lapangan akan memberikan dampak efektif dan signifikan baik secara konseptual maupun aplikatif. Pelatihan secara berkala dan berkelanjutan akan menfasilitasi peserta untuk meningkatkan kompetensi bahasa Inggris secara konsep atau teoritis dan merumuskan solusi dari kendala-kendala yang ditemukan pada sektor pemasaran produk yang dihadapi oleh pengrajin dan pedagang kain tenun. 
Pembinaan lapangan akan memberikan motivasi dan membangun kepercayaan diri peserta dalam memberikan pelayanan wisata secara maksimal khususnya bagi wisatawan asing. Pendampingan dapat pula menjadi koreksi ataupun evaluasi terhadap efektivitas pelatihan bahasa Inggris yang diberikan.

Program kemitraan berupa pelatihan bahasa Inggris melalui Direct Selling akan diberikan kepada pelaku wisata: pengrajin dan pedagang kain tenun yang terdapat di desa Pringgasela. Pelatihan akan diberikan secara berkelompok berdasarkan kemampuan dasar berbahasa Inggris dan usia. Pengrajin dan pedagang kain tenun akan dilatih secara kolektif dengan materi bahasa Inggris yang didesain khusus untuk memasarkan produk dengan percakapan-percakapan praktis dan aplikatif bagi mereka ketika harus berhadapan dengan wisatawan mancanegara, diberikan pula pengetahuan singkat mengenai proses pembuatan kain tenun dalam bahasa Inggris dalam kalimat-kalimat yang singkat dan jelas.

(Tom \& Alan, 2012) menyatakan bahwa dalam pembelajaran sesuai dengan konteks di definisikan sebagai konsep yang membantu guru dan siswa menghubungkan arti kata di dunia nyata dengan subject permasalahan sescara benar. Pendapat ini didukung dengan hasil penelitian yang dilakuakan oleh (Satriani, 2012) yang menyatakan bahwa terdapat beberapa keuntungan dalam menerepakan materi yang sesuai denga konteks, diantaranya (1) menarik siswa untuk aktif dalam proses pembelajaran (2) meningkatkan motivasi belajar siswa (3) membantu siswa untuk menyelesaikan permaslahan (4) membuat siswa untuk diskusi dan berinteraksi dengan teman (5) membantu siswa untuk membuat rangkuman dan merefleksikan pelajaran. Sehuungan dengan hasil penelitian diatas, bahasa Inggris yang sesuai dengan kebutuhan pengrajin dan pedagang gerabah sangat mereka butuhkan atau yang dikenal dengan English for Specific Purposes.

Pembinaan lapangan diberikan kepada peserta selama melakukan aktivitas pelayanan kepada wisatawan nusantara di lapangan secara bergiliran. Proses pendampingan di lapangan dilakukan untuk mengefektifkan percakapan-percakapan praktis dan aplikasi bidang pemasaran yang telah diperoleh peserta di lokasi pelatihan. Hal ini juga dijadikan sebagai bahan evaluasi bagi instruktur untuk mengembangkan proses pelatihan pada jadwal selanjutnya. Untuk efektivitas proses pembinaan, maka satu instruktur akan mendampingin 1 orang pesertanya dalam kelompok belajar dan instruktur dilengkapi dengan lembar observasi untuk mencatat kekurangan yang peserta mungkin alami dilapangan dalam proses pelatihan bahasa Inggris.

Pengrajin dan pedagang kain tenun di desa wisata Pringgasela rata-rata merupakan masyarakat dengan ekonomi rendah. Faktor ekonomi menjadi satu alasan mendasar bagi mereka atas keterbatasan penguasaan bahasa Inggris yang diperoleh mereka melalui pendidikan formal. Rendahnya penguasaan bahasa Inggris tidak membuat mereka patah arang dalam menekuni mata pencaharian sebagai pelaku wisata, dalam hal ini pengrajin dan pedagang kain tenun. Namun kenyataan ini tentunya membawa konsekuensi sendiri bagi mereka, yaitu menjadi kurang proaktif dan cenderung pasif dalam memberikan pelayanan bagi wisatawan asing khususnya dalam hal memasarkan produknya. Fakta inilah yang menjadi alasan penting untuk dilaksanakannya Program Kemitraan Masyarakat di desa wisata Pringgasela.

Program ini bertujuan untuk: 1) Membekali pengrajin dan pedagang kain tenun dengan keterampilan berkomunikasi dalam bahasa Inggris agar mampu memasarkan produk mereka kepada wisatawan asing secara praktis dan efisien, 2) Solusi alternatif agar pengrajin dan pedagang kain tenun tidak lagi bergantung kepada guide dari travel agent untuk memasarkan produk mereka.

\section{METODE PELAKSANAAN}

Mekanisme pelaksanaan kegiatan ini meliputi empat (4) tahap pelaksanaan kegiatan, yaitu; Perencanaan dan koordinasi, tindakan, pendampingan, serta refleksi dan evaluasi.

1. Perencanaan dan Koordinasi

Tahapan perencanaan dan koordinasi meliputi: 
a. Penyusunan program pelatihan bahasa Inggris dan teknik kepemanduan wisata di desa Pringgasela;

b. Berkoordinasi dengan ketua Lembaga Pemerhati Pariwisata, Seni dan Budaya Desa (LP2SBD), tokoh masyarakat, dan tokoh pemuda serta aparat pemerintahan dalam rangka penyuksesan program pelatihan bahasa Inggris Pariwisata dan dan teknik kepemanduan wisata.

\section{Tindakan}

Tindakan merupakan proses pelaksanaan dari perencanaan dan koordinasi program pelatihan bahasa Inggris dan tehnik kepemanduan wisata yang meliputi tahapan-tahapan yang disuaikan dengan program-program yang sudah direncanakan sebelumnya, yaitu;

a. Program Pelatihan Bahasa Inggris Pariwisata

1) Pembentukan kelompok pelatihan bahasa Inggris pariwisata

2) Pemberian materi bahasa Inggris umum dan bahasa Inggris

3) Mengaplikasikan materi kebahasaan yang telah mereka pelajari

b. Program Pelatihan Teknik Kepemanduan (Guiding Technique dan Direct Selling) Program pelatihan teknik kepemanduan wisata disenergikan dengan pelatihan Bahasa Inggris Pariwisata dan akan mendapatkan teknik tersendiri guna memaksimalkan pelayanan terhadap wisatawan baik lokal maupun mancanegara.

3. Pendampingan

Pendampingan dilakukan bersamasama dengan tokoh masyarakat, pemuda dan mitra guna melihat efektivitas dari pelatihan yang dilakukan terhadap capain target yang ditetapkan. Pendampingan akan meliputi aspek-aspek berikut ini:

a. Pendampingan aspek kebahasaan dalam interaksi mereka dengan para wisatawan, serta kemampuan mereka dalam mengembangkan bahasa Inggris.

b. Pandampingan terhadap teknik mereka dalam memandu wisatawan

4. Refleksi dan Evaluasi

Refleksi dan evaluasi dalam kegiatan ini bertujuan untuk meningkatkan kualitasi perencanaan, pelatihan, dan pendampingan dengan mempelajari kelemahan dan kelebihan yang terdapat pada setiap program untuk dapat mendalami permasalahan yang ada dan melakukan perbaikan sehingga program ini bersifat berkelanjutan guna meningkatkan kualitas dan taraf hidup masyarakat desa Pringgasela dan masyarakat sekitarnya.

\section{HASIL DAN PEMBAHASAN (12pt)}

Program PKM ini telah dilakukan dengan hasil capaian sebagai berikut:

\section{Koordinasi Tim PKM}

Koordinasi tim PKM dilakukan pada hari Sabtu, 01 Agustus 2020 di kampus UNDIKMA. Kegiatan ini diikuti oleh Fathurrahman Imran, M.Pd.B.I. (ketua tim), Aprianoto, M.Pd., dan anggota tim lainnya. Pembahasan yang didiskusikan pada kegiatan ini adalah (1) mengatur jadwal pelaksanaan kegiatan PKM, (2) pematangan metode pelatihan dan pendampingan masyarakat dan persiapan materi pelatihan.

Kegiatan koordinasi ini menghasilkan beberapa kesepakatan yaitu (1) pelatihan bahasa inggris pariwisata dimulai tanggal 08 Agustus 2020, (2) tim akan melakukan sosialisasi terlebih dahulu kepada peserta pelatihan agar mereka mengetahui tujuan pelatihan bahasa inggris pariwisata.

\section{Koordinasi dengan Mitra}

Koordinasi dengan mitra dilakukan pada hari 01 Agustus 2020 Pukul 08.30 Wita di kantor LP2SBD

\section{Tindakan}

Pada tahap tindakan, ada tiga kegiatan yang telah dilaksanakan yaitu;

a. Pemberian materi, setelah mereka menerima teori, mereka diminta untuk mempraktekkan materi dalam bentuk percakapan. Selain materi bahasa Inggris, peserta juga dibekali dengan teknik kepemanduan. Harapannya ketika makin banyak wisatawan yang datang khususnya wisatawan mancanegara, mereka bisa mengambil peran sebagai pemandu lokal. Berdasarkan materi yang diberikan dan untuk mengetahui 
peningkatan pemahaman, berikut disajikan dalam diagram dibawah ini:

Tanggapan Peserta Terhadap Pelatihan

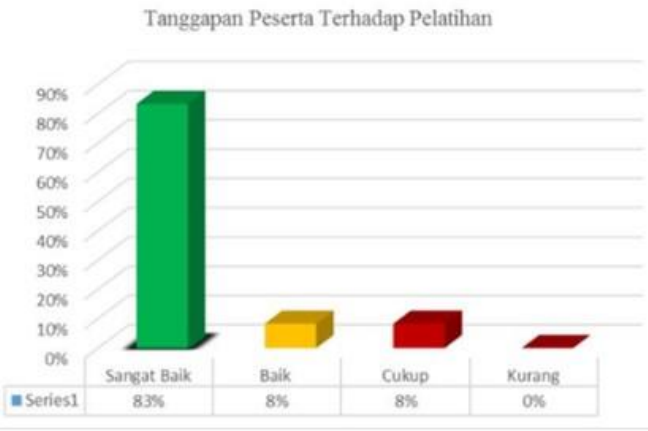

Gambar 1. Tanggapan Peserta Terhadap Materi

b. Pengaplikasian materi

Kelompok dibentuk berdasarkan kemampuan masing-masing peserta yang dimana mereka terlebih dahulu diberikan placeman test.

c. Pendampingan

Tahapan pendampingan akan dilakukan pada tahapan lanjutan. Tahapan ini merupakan kegiatan pasca program PKM. Tim yang dibantu oleh tokoh masyarakat yang tergabung dalam POKDARWIS desa Pringgasela akan terus melakukan pendampingan sampai penerima manfaat bisa mempraktikkan materi yang telah mereka terima. Kekurangan atau kelemahan dalam proses pendampingan, akan dijadikan acuan dalam penguatan materi pelatihan selanjutnya.

\section{Refleksi dan Evaluasi}

Tahapan refleksi dan evaluasi bertujuan untuk meningkatkan kualitas dan sekaligus mempelajari kelebihan dan kelemahan dari program yang telah dilaksanakan yang nantinya dapat digunakan sebagai acuan untuk programprogram selanjutnya.

Selama proses pelatihan, tim pelaksana kegiatan pengabdian melakukan pemantauan kepada peserta pelatihan sekaligus melakukan wawancara terhadap materi, metode dan instruktur dalam kegiatan ini. Secara umum para peserta mengatakan pelatihan ini sangat baik dan materi yang diberikan merupakan materi yang sangat dibutuhkan dalam parawisata sedangkan instrukturnya sangat berkompoten.

\section{KESIMPULAN}

1. Mitra berperan aktif dalam pelaksanaan setiap kegiatan PKM.

2. Peserta memiliki motivasi yang baik dalam mengikuti kegiatan pelatihan bahasa inggris pariwisata.

3. Peserta memiliki kemampuan dan keterampilan dalam berkomunikasi dengan wisatawan asing (luar negeri).

4. Peserta memiliki pemahaman dan keterampilan tentang bahasa inggris pariwisata.

\section{DAFTAR PUSTAKA}

Hardiyanti, A. (2017, Februari Sabtu). Retrieved from https://andyhardiyanti.com/2017/02/ka in-tenun-desa-pringgasela/

Juniati, N. (2020). Kajian Tentang Tenun Sesek dari Desa Pringgasela, Lombok Timur, Nusa Tenggara Barat. Jurnal Sains dan Teknologi, 57.

Satriani. (2012). Contextual teaching and learning approach. Indonesian Journal of Applied Linguistics.

Solihin, M. (2016, April 12 ). kompasiana. Retrieved from kompasiana: https://www.kompasiana.com/solihin9 5/570d088252f9fd1a0a66ffe9/tenungedogan-desa-pringgasela?page $=$ all

Tom, H., \& Alan, W. d. (2012). English for spesific purposes. In H. Tom, \& W. Alan, English for spesific purposes (p. 11). Cambridge University Press. 